\title{
Deliberate self-harm is associated with allelic variation in the tryptophan hydroxylase gene (TPH A779C), but not with polymorphisms in five other serotonergic genes
}

\author{
E. C. POOLEY, K. HOUSTON, K. HAWTON And P. J. HARRISON ${ }^{1}$ \\ From the University Department of Psychiatry and Centre for Suicide Research, Warneford Hospital, \\ University of Oxford
}

\begin{abstract}
Background. There is a heritable component to suicidal behaviour, encouraging the search for the associated risk alleles. Given the putative role of the 5-HT (5-hydroxytryptamine; serotonin) system in suicidal behaviour, serotonergic genes are leading candidates. In particular, several studies have reported an association with variants in the tryptophan hydroxylase (TPH) gene.

Method. We studied six serotonergic gene polymorphisms in a well-characterized sample of 129 deliberate self-harm subjects and 329 comparison subjects. The polymorphisms were TPH (A779C), 5-HT transporter (5-HTT, LPR S/L), monoamine oxidase A (MAOA G941T), 5-HT1B receptor (HTR1B G861C), 5-HT2A receptor (HTR2A T102C), and 5-HT2C receptor (HTR2C Cys23Ser). Genotyping was done using polymerase chain reaction (PCR)-based assays. The primary analyses compared allele and genotype frequencies between cases and controls. There were a limited number of planned secondary analyses within the deliberate self-harm group.
\end{abstract}

Results. The TPH A779 allele was more common in deliberate self-harm subjects than in controls (OR $1 \cdot 38,95 \%$ CI $1 \cdot 02-1 \cdot 88 ; P=0 \cdot 03$ ). None of the other polymorphisms was associated with deliberate self-harm. Within the deliberate self-harm group there were no associations with impulsivity, suicide risk, lifetime history of depression, or family history of deliberate self-harm.

Conclusions. Our data extend the evidence that allelic variation in the TPH gene is a risk factor for deliberate self-harm. No evidence was found to implicate the other polymorphisms.

\section{INTRODUCTION}

Deliberate self-harm (DSH) is the best predictor of future suicide (Sakinofsky, 2000). Suicidal behaviour may result from a wide range of factors (Hawton \& van Heeringen, 2000). Psychiatric and personality disorders are present in most suicides and DSH patients, and comorbidity of disorders, especially mood and substance abuse disorders, is common (Suominen

\footnotetext{
1 Address for correspondence: Dr Paul J. Harrison, Neurosciences Building, University Department of Psychiatry, Warneford Hospital, Oxford OX3 7JX.
}

et al. 1996; Foster et al. 1997; Kessler et al. 1999; Haw et al. 2001). In addition, impulsivity and aggression are traits of behavioural disinhibition that may underlie a cross-diagnostic propensity for suicidal behaviour (Brodsky et al. 1997; Roy, 2001; Van Praag, 2001).

Suicide and DSH show familial clustering (Roy, 1983; Roy et al. 2000; Hawton et al. 2002). Twin and adoption studies show that this familiality is due mainly to genetic factors, which differ from the genetic predisposition to associated psychiatric disorders (Roy, 2001; Turecki, 2001). The latter was confirmed by a 
recent case-control study, which found that suicide is independently associated with a family history of suicide, with an odds ratio of 2.58 (95\% CI, 1.84-3.61) (Qin et al. 2002). An Australian population-based twin study reported that additive genetic effects explained $45 \%$ of the variance in suicidal thoughts and DSH (Statham et al. 1998), while another twin study reported a $17 \%$ genetic contribution to DSH and $36 \%$ to suicidal ideation (Fu et al. 2002). These findings, in conjunction with the importance of suicide and DSH as public health issues, have focused attention on the search for the susceptibility genes for suicidal behaviour. Investigations to date have been almost entirely case-control association studies in which the frequencies of common polymorphisms in candidate genes have been compared between DSH (or suicide) subjects and a control group from the same population. The most widely studied genes have been those involved in 5-HT (serotonergic) neurotransmission, due to prior evidence of 5-HT dysfunction in suicidal individuals and suicide victims, and in associated factors such as impulsivity, aggression, and low mood (Mann, 1998). For example, cerebrospinal fluid (CSF) levels of the major 5-HT metabolite, 5-HIAA (5-hydroxyindoleacetic acid), are reduced in suicide attempters (Åsberg et al. 1976), and suicide victims and those with suicidal ideation exhibit differences in central expression of 5-HT receptors, especially the 5HT2A receptor (HTR2A), and the 5-HT transporter (5-HTT) (see Mann, 1999).

Several suggestive associations between serotonergic genes and either suicide or DSH have been reported, in particular with allelic variation in tryptophan hydroxylase (TPH) (Mann et al. 1997), HTR2A (Du et al. 2000a), 5-HTT (Du et al. 1999) and 5-HT1D $\beta$ receptor (HTR1B) (New et al. 2001). However, as reviewed by Turecki (2001) and Mann et al. (2001), although the first two associations have been replicated at least once, other studies have failed to do so, while still others have reported associations with different serotonergic genes (see Discussion). To extend this body of work, we have examined these four polymorphisms, together with two other 5-HT-related candidate genes (5-HT2C receptor (HTR2C) and monoamine oxidase A (MAOA)), in a well-characterized sample of DSH subjects and a relatively large comparison group drawn from the same population.

\section{METHOD}

\section{Sample selection and recruitment}

The subjects were patients aged 15 years and over who presented to the general hospital in Oxford following an episode of DSH. The definition of DSH was that given for 'parasuicide' in the WHO/EURO Multicentre Study of Suicidal Behaviour (Platt et al. 1992). From the 217 individuals approached, 150 took part in the original interview study, and from these, 129 (52 male, 77 female; mean age 38 years (s.D. $=14$; range 20-72)) provided DNA for the present study. The demographic, psychiatric and personality characteristics of the $150 \mathrm{DSH}$ patients have been documented in detail (Haw et al. 2001); the 129 patients studied here were demographically indistinguishable from the full sample. Subjects were assessed using a structured interview (Haw et al. 2001), generating diagnoses according to ICD-10 research criteria (World Health Organization, 1993). Subjects were also rated using the Beck Suicide Intent Scale (Beck et al. 1974), the Brown-Goodwin Aggression Scale (Brown et al. 1979), and the Plutchik Impulsivity Scale (Plutchik et al. 1989).

The salient clinical characteristics of the sample were as follows. The majority $(96 \%)$ of the DSH acts were self-poisoning. Two-thirds had previously self-harmed at least once. Most $(91 \%)$ patients had an Axis I psychiatric disorder at index. The commonest diagnoses were depressive episode $(72 \%)$, alcohol harmful use or dependence $(29 \%)$, and neurotic/stressrelated disorders $(16 \%)$. Seventy-eight subjects (64\% from a total of 122$)$ had a lifetime history of depressive disorder of at least moderate severity. A self-reported family history of suicide and/or DSH was present in $40 \%$ of subjects (Hawton et al. 2002).

The control sample comprised 329 individuals (138 male, 191 female), mean age 38 years (s.D. $=13$, range 19-71), recruited from blood donor clinics within Oxfordshire. It excluded individuals who reported any history of psychiatric disorder or current psychotropic medication in a self-report questionnaire. All DSH and control subjects were Caucasian and born 
in the UK, as were their parents and all four grandparents.

\section{DNA extraction and genotyping}

Participants provided two buccal swabs from which DNA was extracted using standard techniques (DNAce Clinipure Kit, Bioline, UK). Genotypes for the polymorphisms in the HTR2A, HTR2C, TPH, HTR1B and MAOA genes were determined using a previously described sequence-specific PCR assay (Marshall et al. 1999). Briefly, the assay comprises two reactions - each consisting of the relevant allelespecific primer, the consensus primer, and two control primers (to determine amplification success). Allele-specific primers differ in the 3'terminal nucleotide to allow the different genotypes to be discriminated (details on request). In reactions where the specific primer binds appropriately, two bands are observed - one for the allele specific PCR product and one for the control primer. Each reaction was carried out in a $13 \mu \mathrm{l}$ volume consisting of $67 \mathrm{~mm}$ Tris base, $\mathrm{pH} \mathrm{8.8;} 2$ mм magnesium chloride; $0.01 \% \mathrm{v} / \mathrm{v}$ Tween 20; $16.6 \mathrm{~mm}$ ammonium sulphate; $200 \mu \mathrm{M}$ of each dNTP; between 100-300 ng of DNA template; and 0.2 U BioTaq DNA polymerase (Bioline). All primers were designed to operate within the same range of melting temperatures; the final primer concentrations were $192 \mathrm{pg} / \mu \mathrm{l}$, with the exception of the HTR2C primers $(96 \mathrm{pg} / \mu \mathrm{l})$ and the control primers $(38 \mathrm{pg} / \mu \mathrm{l})$. Thermal cycling parameters consisted of an initial denaturation at $96^{\circ} \mathrm{C}$ for $60 \mathrm{~s}$ followed by five cycles of $96^{\circ} \mathrm{C}$ for $20 \mathrm{~s}, 67^{\circ} \mathrm{C}$ for $45 \mathrm{~s}$ and $72{ }^{\circ} \mathrm{C}$ for $25 \mathrm{~s}$. Two subsequent stages followed - first, 26 cycles of $96{ }^{\circ} \mathrm{C}$ for $25 \mathrm{~s}, 60{ }^{\circ} \mathrm{C}$ for $50 \mathrm{~s}$ and $72{ }^{\circ} \mathrm{C}$ for $30 \mathrm{~s}$, then four cycles of $96{ }^{\circ} \mathrm{C}$ for $30 \mathrm{~s}, 55^{\circ} \mathrm{C}$ for $60 \mathrm{~s}$, and $72{ }^{\circ} \mathrm{C}$ for $90 \mathrm{~s}$. Samples were cooled to $4{ }^{\circ} \mathrm{C}$, centrifuged, and visualized on $1.5 \%$ agarose gels containing $0.5 \mu \mathrm{g} / \mathrm{ml}$ ethidium bromide.

Genotyping of the 5-HTT LPR short/long promoter variant was determined separately, using primers directed to the adjacent upstream and downstream regions of the insertion/ deletion site. A $20 \mu \mathrm{l}$ reaction volume consisted of $1.5 \mathrm{~mm}$ magnesium chloride; $200 \mu \mathrm{M}$ of each dNTP; $5 \%$ dimethylsulphoxide; approximately $200 \mathrm{ng}$ of DNA template; and $1 \mathrm{U}$ BioTaq DNA polymerase together with the appropriate volume of 10X BioTaq reaction buffer. The final concentration of the forward (5'-GCG TTG CCG CTC TGA ATG C-3') and reverse (5'GGA CTG AGC TGG ACA ACC AC-3') primers was $625 \mathrm{pg} / \mu \mathrm{l}$. Cycling parameters were: $95^{\circ} \mathrm{C}$ for $120 \mathrm{~s}$, two cycles at $95^{\circ} \mathrm{C}$ for $30 \mathrm{~s}$, $63{ }^{\circ} \mathrm{C}$ for $30 \mathrm{~s}$, and $72{ }^{\circ} \mathrm{C}$ for $60 \mathrm{~s}$, prior to two cycles at $95{ }^{\circ} \mathrm{C}$ for $30 \mathrm{~s}, 62{ }^{\circ} \mathrm{C}$ for $30 \mathrm{~s}$ and $72{ }^{\circ} \mathrm{C}$ for $60 \mathrm{~s}$, followed by 35 cycles at $95^{\circ} \mathrm{C}$ for $30 \mathrm{~s}$, $61{ }^{\circ} \mathrm{C}$ for $30 \mathrm{~s}$ and $72{ }^{\circ} \mathrm{C}$ for $60 \mathrm{~s}$, with a final elongation step for $8 \mathrm{~min}$ at $72{ }^{\circ} \mathrm{C}$. PCR fragments were resolved on a $3 \%$ agarose gel and visualized with $0.5 \mu \mathrm{g} / \mathrm{ml}$ ethidium bromide.

Every polymorphism was genotyped twice for each individual, and alleles were scored independently by two people. For the few samples where there was an inconclusive result or discrepancy between duplicates, genotyping was repeated until an unequivocal genotype was obtained.

\section{Statistical analysis}

The primary analysis was the comparison of genotype and allele frequencies between cases and controls using $\chi^{2}$ tests. For the HTR2C and MAOA polymorphisms, men and women were analysed separately since males are hemizygous for X-linked genes. In addition, four planned secondary analyses were performed within the DSH sample, limited to those polymorphisms that showed a positive overall association with DSH in the present study, or where a prior association had been reported. The secondary analyses were: (1) the presence or absence of a lifetime history of major depression; (2) the presence or absence of a family history of suicidal behaviour; (3) the relationship with impulsivity, assessed using the Plutchik scale, for which scores ranged from 21-53, with a mean (s.D.) of $36 \cdot 0(6 \cdot 4)$, available in 121 subjects; (4) finally, we produced a composite score for risk of suicide ('suicide risk score'), which was the sum of the quartile scores obtained from the Brown-Goodwin Aggression Scale, the Beck Suicide Intent Scale, and the number of lifetime DSH episodes divided into quartiles. This gave a range of possible scores from 3 to 12 , and was available for 120 of the DSH patients. In males, the suicide risk score ranged from 4 to 12 , with a mean of $7 \cdot 8$, and in females ranged from 3 to 12 , with a mean of 6.9 . 
Table 1. Allele and genotype frequencies in DSH and control groups, for the autosomal genes

\begin{tabular}{|c|c|c|c|c|}
\hline & $\begin{array}{l}\text { DSH group } \\
(N=129)\end{array}$ & $\begin{array}{l}\text { Control group } \\
\quad(N=329)\end{array}$ & $\chi^{2}$ & $P$ \\
\hline \multicolumn{5}{|l|}{ ТРН A779C } \\
\hline \multicolumn{5}{|l|}{ Genotype } \\
\hline A779/A779 & $20(0 \cdot 16)$ & $44(0 \cdot 13)$ & \multirow[t]{3}{*}{$6 \cdot 55$} & \multirow[t]{3}{*}{$0 \cdot 04$} \\
\hline A $779 / C 779$ & $67(0 \cdot 52)$ & $135(0 \cdot 41)$ & & \\
\hline C779/C779 & $42(0 \cdot 34)$ & $150(0 \cdot 46)$ & & \\
\hline \multicolumn{5}{|l|}{ Allele } \\
\hline A779 & $107(0 \cdot 41)$ & $223(0 \cdot 34)$ & \multirow[t]{2}{*}{$4 \cdot 62$} & \multirow[t]{2}{*}{0.03} \\
\hline $\mathrm{C} 779$ & $151(0 \cdot 59)$ & $435(0 \cdot 66)$ & & \\
\hline \multicolumn{5}{|l|}{ HTR1B G861C } \\
\hline \multicolumn{5}{|l|}{ Genotype } \\
\hline G861/G861 & $77(0 \cdot 6)$ & $194(0 \cdot 59)$ & \multirow[t]{3}{*}{$0 \cdot 17$} & \multirow[t]{3}{*}{$0 \cdot 91$} \\
\hline G861/C861 & $44(0.34)$ & $111(0 \cdot 34)$ & & \\
\hline C861/C861 & $8(0.06)$ & $24(0 \cdot 07)$ & & \\
\hline \multicolumn{5}{|l|}{ Allele } \\
\hline G861 & $198(0 \cdot 77)$ & $499(0 \cdot 76)$ & \multirow[t]{2}{*}{0.08} & \multirow[t]{2}{*}{$0 \cdot 77$} \\
\hline C861 & $60(0 \cdot 23)$ & $159(0 \cdot 24)$ & & \\
\hline \multicolumn{5}{|l|}{ HTR2A T102C } \\
\hline \multicolumn{5}{|l|}{ Genotype } \\
\hline T102/T102 & $17(0 \cdot 13)$ & $43(0 \cdot 13)$ & \multirow[t]{3}{*}{$1 \cdot 01$} & \multirow[t]{3}{*}{$0 \cdot 60$} \\
\hline $\mathrm{T} 102 / \mathrm{C} 102$ & $70(0.54)$ & $163(0.50)$ & & \\
\hline $\mathrm{C} 102 / \mathrm{C} 102$ & $42(0 \cdot 33)$ & $123(0 \cdot 37)$ & & \\
\hline \multicolumn{5}{|l|}{ Allele } \\
\hline T102 & $104(0 \cdot 40)$ & $249(0 \cdot 38)$ & \multirow[t]{2}{*}{$0 \cdot 48$} & \multirow[t]{2}{*}{$0 \cdot 49$} \\
\hline $\mathrm{C} 102$ & $154(0 \cdot 60)$ & $409(0 \cdot 62)$ & & \\
\hline \multicolumn{5}{|l|}{ 5-HTT LPR } \\
\hline \multicolumn{5}{|l|}{ Genotype } \\
\hline $\mathrm{S} / \mathrm{S}$ & $25(0 \cdot 19)$ & $65(0 \cdot 20)$ & \multirow[t]{3}{*}{$0 \cdot 14$} & \multirow[t]{3}{*}{0.93} \\
\hline $\mathrm{S} / \mathrm{L}$ & $66(0 \cdot 51)$ & $160(0 \cdot 49)$ & & \\
\hline $\mathrm{L} / \mathrm{L}$ & $38(0 \cdot 30)$ & $100(0 \cdot 31)$ & & \\
\hline \multicolumn{5}{|l|}{ Allele } \\
\hline $\mathrm{S}$ & $116(0 \cdot 45)$ & $290(0 \cdot 44)$ & \multirow[t]{2}{*}{$0 \cdot 01$} & \multirow[t]{2}{*}{0.92} \\
\hline $\mathrm{L}$ & $142(0 \cdot 55)$ & $360(0 \cdot 56)$ & & \\
\hline
\end{tabular}

Numbers in parentheses indicate allele or genotype frequency.

\section{RESULTS}

Allele and genotype data for the six polymorphisms in the DSH and control groups are given for the autosomal genes in Table 1, and the X-linked genes in Table 2. All results were in Hardy-Weinberg equilibrium and were very similar to previously reported allele frequencies within Caucasian populations (Gelernter et al. 1997; Marshall et al. 1999). The main positive finding is that the TPH A779 allele was more common in the DSH sample than in the controls (Table 1: $\mathrm{OR}=1 \cdot 38, \quad 95 \%$ CI $1.02-1 \cdot 88$; $P=0.03)$. There were no significant differences or trends between cases and controls for any of the other polymorphisms (all $P>0 \cdot 25$ ).

\section{Planned secondary analyses within the DSH group}

Table 3 summarizes the secondary analyses. No significant differences in allele or genotype frequencies were found related to a family history of DSH, lifetime history of depression, or with suicide risk scale or impulsivity score, for any of the four genes for which these planned comparisons were carried out. In addition, because of the finding of Evans et al. (2000), we examined whether the HTR2C Ser23 variant was associated with impulsivity score, but found no such relationship (Cys, 36.7 $\pm 7 \cdot 2, N=44$; Ser, $38 \cdot 8 \pm 4 \cdot 8 ; N=5$ ).

\section{DISCUSSION}

\section{Allelic variation in 5-HT-related genes and DSH}

We found a significant association between DSH and the A779 polymorphism of the tryptophan hydroxylase gene (Table 1). (The A779 and C779 alleles are alternatively referred to as ' $U$ ' and ' $L$ ' respectively.) This replicates the original finding of Mann and colleagues (1997) in a group of subjects with major depression. The A779C polymorphism is in almost complete linkage disequilibrium with another TPH polymorphism, A218C. That is, virtually all individuals either have $\mathrm{A}$ alleles at both positions, or $\mathrm{C}$ alleles at both positions. Hence, it is notable that four studies have shown an association of suicidal behaviour with the A218 allele, since these are effectively also replications of the A779 finding (Persson, 1999; Tsai et al. 1999a; Abbar et al. 2001; Courtet et al. 2002). These data together make a relatively convincing case that the A779/A218 variant of the TPH gene is associated with DSH. However, other results have been negative (Furlong et al. 1998; Zalsman et al. 2001) or equivocal (Geijer et al. 2000), and no association has been found with completed suicide (Bennett et al. 2000; Du et al. 2000 b; Ono et al. 2000; Turecki et al. 2001). Moreover, the opposite association (i.e. with the C779 allele) has also been reported (Nielsen et al. 1994, 1998), albeit in a sample of alcoholic, violent offenders and arsonists, who represent a markedly different clinical population from that of typical DSH subjects.

The molecular mechanism by which the A779C and A218C polymorphisms might mediate their effects on DSH remains unclear. Both are intronic and therefore do not alter the amino-acid sequence. Two alternative possibilities remain: they may affect the processing of the TPH gene transcript (e.g. alter RNA 
Table 2. Allele and genotype frequencies for the X-linked genes in the DSH and control groups

\begin{tabular}{|c|c|c|c|c|c|c|c|c|}
\hline & $\begin{array}{l}\text { DSH males } \\
(N=52)\end{array}$ & $\begin{array}{l}\text { Control males } \\
\quad(N=138)\end{array}$ & $\chi^{2}$ & $P$ & $\begin{array}{l}\text { DSH females } \\
\quad(N=77)\end{array}$ & $\begin{array}{c}\text { Control females } \\
\quad(N=191)\end{array}$ & $\chi^{2}$ & $P$ \\
\hline \multicolumn{9}{|c|}{ HTR2C Cys23Ser } \\
\hline \multicolumn{9}{|c|}{ Genotype } \\
\hline CysCys & & & & & $51(0 \cdot 66)$ & $136(0 \cdot 71)$ & $2 \cdot 03$ & $0 \cdot 36$ \\
\hline CysSer & & & & & $22(0 \cdot 29)$ & $51(0 \cdot 27)$ & & \\
\hline SerSer & & & & & $4(0 \cdot 05)$ & $4(0.03)$ & & \\
\hline \multicolumn{9}{|l|}{ Allele } \\
\hline Cys & $45(0 \cdot 87)$ & $112(0 \cdot 81)$ & $0 \cdot 76$ & $0 \cdot 38$ & $124(0 \cdot 81)$ & $323(0 \cdot 85)$ & $1 \cdot 29$ & $0 \cdot 26$ \\
\hline Ser & $7(0 \cdot 13)$ & $26(0 \cdot 19)$ & & & $30(0 \cdot 19)$ & $59(0 \cdot 15)$ & & \\
\hline \multicolumn{9}{|c|}{ MAOA G941T } \\
\hline \multicolumn{9}{|c|}{ Genotype } \\
\hline GG & & & & & $5(0 \cdot 07)$ & $22(0 \cdot 12)$ & 1.54 & $0 \cdot 46$ \\
\hline GT & & & & & $34(0 \cdot 44)$ & $81(0 \cdot 42)$ & & \\
\hline TT & & & & & $38(0 \cdot 49)$ & $88(0 \cdot 46)$ & & \\
\hline \multicolumn{9}{|l|}{ Allele } \\
\hline G & $17(0 \cdot 33)$ & $37(0 \cdot 27)$ & $0 \cdot 64$ & $0 \cdot 42$ & $44(0 \cdot 29)$ & $125(0 \cdot 33)$ & 0.88 & $0 \cdot 35$ \\
\hline $\mathrm{T}$ & $35(0.67)$ & $101(0 \cdot 73)$ & & & $110(0 \cdot 71)$ & $257(0.67)$ & & \\
\hline
\end{tabular}

Numbers in parentheses indicate allele or genotype frequency.

splicing), or else they are merely markers of another, functional, variant which is in linkage disequilibrium with them both. The first possibility is unlikely since neither variant is associated with the production of aberrant TPH splice products (Nielsen et al. 1997). Recent evidence does lend some support to the second proposal. There are four polymorphisms within the TPH promoter sequence, which are in varying degrees of linkage disequilibrium with the A779C and $\mathrm{A} 218 \mathrm{C}$ polymorphisms. Certain haplotypes (combinations of these polymorphisms) are more frequent in suicide attempters (Rotondo et al. 1999) and completers (Turecki et al. 2001). Promoter polymorphisms have functional consequences by virtue of quantitative effects on expression of the gene. Although this has not been shown directly for TPH, preliminary evidence is consistent with the possibility (Rotondo et al. 1999). Whatever the molecular mechanism, the polymorphism is functional, at least in men, with the A779 variant being associated with lower CSF 5-HIAA levels (Jonsson et al. 1997) and an attenuated prolactin response to fenfluramine (Manuck et al. 1999).

Previous studies of the 5-HTT LPR polymorphism and suicidal behaviour have produced conflicting results. The $\mathrm{S}$ (short) allele, which is associated with a lower basal transcriptional activity of the 5-HTT promoter, has been found to be more common in female suicide attempters (Baca-García et al. 2002) and in alcoholics who attempt suicide, especially where the method is violent (Bondy et al. 2000). Conversely, the long allele was reported to be more frequent in depressed suicide victims ( $\mathrm{Du}$ et al. 1999), and the LL genotype was more frequent in a subgroup of suicidal in-patients who scored highly for hopelessness and suicidal intent (Russ et al. 2000). Several other reports indicate no association with either allele (Mann et al. 2000; Geijer et al. 2000), and our finding (Table 1) adds to the tally of negative studies.

The HTR2A C102 allele has been associated with suicidal ideation (Du et al. 2000a) and a history of suicidal behaviour (Arias et al. 2001) among patients with major depression. However, in line with three other studies of suicide and suicidal behaviour (Crawford et al. 1999; Tsai et al. 1999 b; Turecki et al. 1999) we did not find any association of this polymorphism with DSH (Table 1), or in the subgroup comparisons within the DSH sample (Table 3). Moreover, Zhang et al. (1997) reported a weak association between DSH and the T102 allele. Overall therefore, as with the 5-HTT LPR polymorphism, there is no consistent evidence regarding a relationship between HTR2A gene variation and DSH.

New et al. (2001) reported that the intronic G861 variant of the HTR1B gene was associated with a history of suicide attempt in personality disorder subjects. We did not find any association of this polymorphism with DSH (Table 1) or with any of the DSH subgroups (Table 3). Our negative result is in line with the report by 
Table 3. Allele and genotype frequencies within subgroups of the DSH sample

\begin{tabular}{|c|c|c|c|c|c|c|}
\hline & \multicolumn{2}{|c|}{ Family history of suicidal behaviour } & \multicolumn{2}{|c|}{ Lifetime history of depression } & \multirow{2}{*}{$\begin{array}{l}\text { Suicide risk score } \\
\qquad(N=120)\end{array}$} & \multirow{2}{*}{$\begin{array}{c}\text { Impulsivity score } \\
(N=121)\end{array}$} \\
\hline & Present $(N=52)$ & Absent $(N=77)$ & Present $(N=78)$ & Absent $(N=44)$ & & \\
\hline \multicolumn{7}{|c|}{ ТРН A779C } \\
\hline \multicolumn{7}{|c|}{ Genotype } \\
\hline AA & $8(0 \cdot 15)$ & $12(0 \cdot 15)$ & $11(0 \cdot 14)$ & $7(0 \cdot 16)$ & $7 \cdot 5 \pm 2 \cdot 3$ & $36 \cdot 2 \pm 7 \cdot 6$ \\
\hline $\mathrm{AC}$ & $24(0 \cdot 39)$ & $43(0 \cdot 56)$ & $42(0 \cdot 54)$ & $21(0 \cdot 48)$ & $7 \cdot 3 \pm 2 \cdot 3$ & $35 \cdot 9 \pm 5 \cdot 6$ \\
\hline $\mathrm{CC}$ & $20(0 \cdot 46)$ & $22(0 \cdot 29)$ & $25(0 \cdot 32)$ & $16(0 \cdot 36)$ & $7 \cdot 1 \pm 2 \cdot 0$ & $36 \cdot 7 \pm 6 \cdot 9$ \\
\hline \multicolumn{7}{|l|}{ Allele } \\
\hline A & $40(0 \cdot 38)$ & $67(0 \cdot 44)$ & $64(0 \cdot 41)$ & $35(0 \cdot 40)$ & & \\
\hline $\mathrm{C}$ & $64(0 \cdot 62)$ & $87(0 \cdot 56)$ & $92(0 \cdot 59)$ & $53(0 \cdot 60)$ & & \\
\hline \multicolumn{7}{|c|}{ HTR1B G861C } \\
\hline \multicolumn{7}{|c|}{ Genotype } \\
\hline GG & $31(0 \cdot 60)$ & $46(0 \cdot 60)$ & $45(0 \cdot 58)$ & $26(0 \cdot 59)$ & $7 \cdot 3 \pm 2 \cdot 1$ & $36 \cdot 1 \pm 6 \cdot 3$ \\
\hline $\mathrm{GC}$ & $19(0 \cdot 36)$ & $25(0 \cdot 32)$ & $31(0 \cdot 40)$ & $13(0 \cdot 30)$ & $7 \cdot 5 \pm 2 \cdot 4$ & $35 \cdot 6 \pm 5 \cdot 9$ \\
\hline $\mathrm{CC}$ & $2(0 \cdot 04)$ & $6(0 \cdot 08)$ & $2(0.03)$ & $5(0 \cdot 11)$ & $5 \cdot 7 \pm 2 \cdot 0$ & $37 \cdot 7 \pm 10 \cdot 0$ \\
\hline \multicolumn{7}{|l|}{ Allele } \\
\hline G & $81(0 \cdot 78)$ & $117(0 \cdot 76)$ & $121(0 \cdot 78)$ & $65(0 \cdot 74)$ & & \\
\hline $\mathrm{C}$ & $23(0 \cdot 22)$ & $37(0 \cdot 24)$ & $35(0 \cdot 22)$ & $23(0 \cdot 26)$ & & \\
\hline \multicolumn{7}{|c|}{ HTR2A T102C } \\
\hline \multicolumn{7}{|c|}{ Genotype } \\
\hline TT & $5(0 \cdot 10)$ & $12(0 \cdot 16)$ & $9(0 \cdot 12)$ & $7(0 \cdot 16)$ & $7 \cdot 4 \pm 2 \cdot 6$ & $37 \cdot 4 \pm 7 \cdot 3$ \\
\hline $\mathrm{TC}$ & $30(0 \cdot 58)$ & $40(0 \cdot 52)$ & $43(0.55)$ & $24(0.55)$ & $6 \cdot 9 \pm 2 \cdot 2$ & $35 \cdot 9 \pm 6 \cdot 5$ \\
\hline $\mathrm{CC}$ & $17(0 \cdot 33)$ & $25(0 \cdot 32)$ & $26(0 \cdot 33)$ & $13(0 \cdot 30)$ & $7 \cdot 7 \pm 1 \cdot 9$ & $35 \cdot 7 \pm 5 \cdot 9$ \\
\hline \multicolumn{7}{|l|}{ Allele } \\
\hline $\mathrm{T}$ & $40(0 \cdot 38)$ & $64(0.42)$ & $61(0 \cdot 39)$ & $38(0 \cdot 43)$ & & \\
\hline $\mathrm{C}$ & $64(0 \cdot 62)$ & $90(0 \cdot 58)$ & $95(0 \cdot 61)$ & $50(0 \cdot 57)$ & & \\
\hline \multicolumn{7}{|c|}{ 5-HTT LPR } \\
\hline \multicolumn{7}{|c|}{ Genotype } \\
\hline SS & $13(0 \cdot 25)$ & $12(0 \cdot 16)$ & $13(0 \cdot 17)$ & $12(0 \cdot 25)$ & $7 \cdot 3 \pm 2 \cdot 6$ & $36 \cdot 3 \pm 6 \cdot 1$ \\
\hline SL & $25(0.48)$ & $41(0 \cdot 53)$ & $41(0.53)$ & $25(0.45)$ & $7 \cdot 1+2 \cdot 2$ & $36 \cdot 0 \pm 7 \cdot 0$ \\
\hline LL & $14(0 \cdot 27)$ & $24(0 \cdot 31)$ & $24(0 \cdot 31)$ & $14(0 \cdot 29)$ & $7 \cdot 5 \pm 2 \cdot 0$ & $35 \cdot 9 \pm 5 \cdot 7$ \\
\hline \multicolumn{7}{|l|}{ Allele } \\
\hline $\mathrm{S}$ & $51(0 \cdot 49)$ & $65(0 \cdot 42)$ & $67(0 \cdot 43)$ & $49(0 \cdot 48)$ & & \\
\hline $\mathrm{L}$ & $53(0 \cdot 51)$ & $89(0 \cdot 54)$ & $89(0 \cdot 59)$ & $53(0 \cdot 52)$ & & \\
\hline
\end{tabular}

Numbers in parentheses indicate allele or genotype frequency. Scores are mean \pm s.D.

Huang et al. (1999) in suicide victims. We also found no association between DSH and the silent G941T polymorphism in the MAOA gene, in either men or women (Table 2), in agreement with Ho et al. (2000).

Frequencies for the HTR2C Cys23Ser polymorphism did not differ in this study between DSH and control men or women (Table 2). There have been no prior investigations of this association with DSH, although the Ser23 variant has been associated with higher impulsivity scores in men, but not women, presenting after DSH (Evans et al. 2000). We did not find a relationship between the Ser23 allele and impulsivity, rated with the Plutchik scale. A possible reason for the differing results is that Evans and colleagues (2000) used a different measure of impulsivity. They also had a larger sample, making our study relatively under powered to replicate the finding.

\section{Methodological issues}

Our findings are potentially affected by various limitations of case-control association studies (Malhotra \& Goldman, 1999; Cardon \& Bell, 2001). The first, hidden population stratification, is relatively unlikely given our careful matching of groups for ethnicity. In any event, recent empirical data suggest that it is less of a concern than was thought (Wacholder et al. 2000; Ardlie et al. 2002). Secondly, like most studies in the field, our $P$ values are uncorrected for multiple testing, and their interpretation must take into account the low prior probability that a given polymorphism, even within a convincing candidate gene, is truly associated with a trait. However, our positive finding with the TPH A779C allele was a replication, and so may be considered less vulnerable to this criticism; moreover, we have not studied 
any polymorphisms other than those presented here, partially reducing the problem of multiple testing. We also note that there is no accepted statistical solution to the issue, and Bonferroni corrections may be inappropriate (Cardon \& Bell, 2001). Regarding the converse problem false negative results due to lack of power - our sample size was larger than most prior studies, for which the average has been approximately 90 DSH subjects and 100 controls (Roy, 2001; Turecki, 2001). Furthermore, none of the polymorphisms showed a non-significant trend towards an association with DSH, which might be suggestive of a type II error (Tables 1 and 2). Nevertheless, because of the risks of false positive and false negative results, additional and larger studies are needed to confirm the present findings, as well as to ascertain the role of rarer allelic variants in serotonergic genes.

A strength of the present study is that the DSH sample was particularly well characterized (Haw et al. 2001; Hawton et al. 2002), and representative of DSH patients attending hospital in the UK (with the exclusion of repetitive selfcutting). A weakness, as in most studies of behavioural phenotypes, is that we lacked full information about the relevant behaviour in the comparison group. Epidemiological studies indicate that between $1 \cdot 1$ and $4.6 \%$ of adults report a lifetime history of DSH (Moscicki, 1997; Kessler et al. 1999) and we assume that these data apply to blood donors. However, it seems highly unlikely that this could have confounded either the positive TPH A779 result, or the negative findings regarding the other polymorphisms.

A final question concerns the actual trait with which the TPH A779C polymorphism is associated. Genetic factors may be more closely related to intermediate phenotypes such as impulsivity, aggression, or severity of suicidal intent, rather than to DSH itself (e.g. Nielsen et al. 1998; Manuck et al. 1999; Evans et al. 2000). For these reasons, we analysed the impulsivity score, and created the composite suicide risk score which included a measure of aggression. We found no evidence that either of these indices was related to the polymorphisms (Table 3 ), suggesting that these factors do not account for the association between DSH and the TPH A779 allele. However, it may instead be that the various scales do not adequately capture the behaviour of interest, or reflect the lack of power of these subgroup analyses. Also, there are many other variables about which we had no information and which might correlate with $\mathrm{DSH}$; for example, the TPH A779 variant has been associated with smoking behaviours (Lerman et al. 2001; Sullivan et al. 2001). These considerations indicate that future genetic studies will benefit from even more extensive characterization of subjects in both DSH and control groups.

\section{Summary}

The heritability of DSH, like that of other complex behavioural phenotypes, presumably reflects the influence of many genes and their interactions, both with each other, and with environmental factors. Association studies of the kind reported here provide initial clues as to the alleles and genes involved. However, they suffer from intrinsic limitations, as mentioned above. Therefore, while well-replicated positive results, such as the association between the TPH gene and DSH are noteworthy and merit further investigation, as well as meta-analyses when sufficient comparable data are available, significant progress in understanding the genetic contributions to suicidal behaviour will also require family-based association studies, genome-wide scans and haplotype analyses.

This work was funded by the American Foundation for Suicide Prevention, and the Anglia and Oxford Research and Development Committee. Edward C. Pooley held a Medical Research Council studentship. Keith Hawton is funded by the Oxfordshire Mental Healthcare Trust. Technical assistance was provided by Khatija Parekh and Louise Hutchinson; Ms Parekh is funded by a grant to the Medical Research Council 'Neurobiology of Mood Disorders' CoOperative Group. We are very grateful to Drs S. Marshall and K. Welsh for their help establishing the allele-specific PCR, Drs P. Burnet and M. Sodhi for technical advice and Drs E. Townsend and C. Haw for assistance in the collection and processing of the clinical data.

\section{REFERENCES}

Abbar, M., Courtet, P., Bellivier, F., Leboyer, M., Boulenger, J. P., Castelhau, D., Ferreira, M., Lambercy, C., Mouthon, D., PaoloniGiacobino, A., Vessaz, M., Malafosse, A. \& Buresi, C. (2001). Suicide attempts and the tryptophan hydroxylase gene. Molecular Psychiatry 6, 268-273. 
Ardlie, K. G., Lunetta, K. L. \& Seielstad, M. (2002). Testing for population subdivision and association in four case-control studies. American Journal of Human Genetics 71, 304-311.

Arias, B., Gasto, C., Catalan, R., Gutierrez, B., Pintor, L. \& Fananas, L. (2001). The 5-HT2A receptor gene $102 \mathrm{~T} / \mathrm{C}$ polymorphism is associated with suicidal behavior in depressed patients. American Journal of Medical Genetics (Neuropsychiatric Genetics) 105 , 801-904.

Åsberg, M., Traskman, L. \& Thoren, P. (1976). 5-HIAA in the cerebrospinal fluid. A biochemical suicide predictor? Archives of General Psychiatry 33, 193-1197.

Baca-García, E., Vaquero, C., Diaz-Sastre, C., Saiz-Ruiz, J., Fernandez-Piqueras, J. \& de Leon, J. (2002). A gender-specific association between the serotonin transporter gene and suicide attempts. Neuropsychopharmacology 26, 692-695.

Beck, A., Schuyler, D. \& Herman, J. (1974). Development of suicidal intent scales. In The Prediction of Suicide (ed. A. Beck, H. Resnick and A. Lettieri), pp. 45-48. Charles Press: Bowie, MD.

Bennett, P. J., McMahon, W. M., Watabe, J., Achilles, J., Bacon, M., Coon, H., Grey, T., Keller, T., Tate, D., Tcaciuc, I., Workman, J. \& Gray, D. (2000). Tryptophan hydroxylase polymorphisms in suicide victims. Psychiatric Genetics 10, 13-17.

Bondy, B., Erfurth, A., de Jonge, S., Kruger, M. \& Meyer, H. (2000). Possible association of the short allele of the serotonin transporter promoter gene polymorphism (5-HTTLPR) with violent suicide. Molecular Psychiatry 5, 193-195.

Brodsky, B. S., Malone, K. M., Ellis, S. P., Dulit, R. A. \& Mann, J. J. (1997). Characteristics of borderline personality disorder associated with suicidal behavior. American Journal of Psychiatry 154, 1715-1719.

Brown, G., Goodwin, F., Ballenger, J., Goyer, P. \& Major, L. (1979). Aggression in humans correlates with cerebrospinal fluid metabolites. Psychiatry Research 1, 131-139.

Cardon, L. R. \& Bell, J. I. (2001). Association study designs for complex diseases. Nature Reviews Genetics 2, 91-99.

Courtet, P., Buresi, C., Baud, P., Astruc, B., Jollant, F., Tores, S. \& Malafosse, A. (2002). Tryptophan hydroxylase and MAOA genes in suicidal behaviour. American Journal of Medical Genetics (Neuropsychiatric Genetics) 114, 735.

Crawford, J., Sutherland, G. \& Goldney, R. D. (1999). No evidence for association of 5-HT2A receptor polymorphism with suicide. American Journal of Medical Genetics (Neuropsychiatric Genetics) 96, 879-880.

Du, L., Faludi, G., Palkovits, M., Demeter, E., Bakish, D., Lapierre, Y. D., Sotonyi, P. \& Hrdina, P. D. (1999). Frequency of long allele in serotonin transporter gene is increased in depressed suicide victims. Biological Psychiatry 46, 196-201.

Du, L., Bakish, D., Lapierre, Y. D., Ravindran, A. V. \& Hrdina, P. D. $(2000 a)$. Association of polymorphism of serotonin $2 \mathrm{~A}$ receptor gene with suicidal ideation in major depressive disorder. American Journal of Medical Genetics 96, 56-60.

Du, L., Faludi, G., Palkovits, M., Bakish, D. \& Hrdina, P. D. $(2000 \mathrm{~b})$. Tryptophan hydroxylase $218 \mathrm{~A} / \mathrm{C}$ polymorphism is not associated with depressed suicide. International Journal of Neuropsychopharmacology 3, 215-220.

Evans, J., Reeves, B., Platt, H., Leibenau, A., Goldman, D., Jefferson, K. \& Nutt, D. (2000). Impulsiveness, serotonin genes and repetition of deliberate self-harm (DSH). Psychological Medicine 30, 1327-1334

Foster, T., Gillespie, K. \& McClelland, R. (1997). Mental disorders and suicide in Northern Ireland. British Journal of Psychiatry 170, 447-452.

Fu, Q., Heath, A. C., Bucholz, K. K., Nelson, E. C., Glowinski, A. L., Goldberg, J., Lyons, M. J., Tsuang, M. T., Jacob, T., True, M. R. \& Eisen, S. A. (2002). A twin study of genetic and environmental influences on suicidality in men. Psychological Medicine 32, $11-24$.

Furlong, R. A., Ho, L., Rubinsztein, J. S., Walsh, C., Paykel, E. \& Rubinsztein, D. C. (1998). No association of the tryptophan hydroxylase gene with bipolar affective disorder, unipolar affective disorder, or suicidal behaviour in major affective disorder. American Journal of Medical Genetics 81, 245-247.

Geijer, T., Frisch, A., Persson, M. L., Wasserman, D., Rockah, R., Michaelovsky, E., Apter, A., Jonsson, E. G., Nothen, M. M. \& Weizman, A. (2000). Search for association between suicide attempt and serotonergic polymorphisms. Psychiatric Genetics 10, $19-26$.

Gelernter, J., Kranzler, H. \& Cubells, J. F. (1997). Serotonin transporter protein (SLC6A4) allele and haplotype frequencies and linkage disequilibria in African- and European-American and Japanese populations and in alcohol-dependent subjects. Human Genetics 101, 243-246.

Haw, C., Hawton, K., Houston, K. \& Townsend, E. (2001). Psychiatric and personality disorders in deliberate self-harm patients. British Journal of Psychiatry 178, 48-54.

Hawton, K. \& van Heeringen, K. (2000). The International Handbook of Suicide and Attempted Suicide. John Wiley: Chichester.

Hawton, K., Haw, C., Houston, K. \& Townsend, E. (2002). Family history of suicidal behaviour: prevalence and significance in deliberate self-harm patients. Acta Psychiatrica Scandinavica 106, 387-393

Ho, L. K., Furlong, R. A., Rubinsztein, J. S., Walsh, C., Paykel, E. S. \& Rubensztein, D. C. (2000). Genetic associations with clinical characteristics in bipolar affective disorder and recurrent unipolar depressive disorder. American Journal of Medical Genetics 96, 36-42.

Huang, Y. Y., Grailhe, R., Arango, V., Hen, R. \& Mann, J. J. (1999). Relationship of psychopathology to the human serotonin1B genotype and receptor binding kinetics in postmortem brain tissue. Neuropsychopharmacology 21, 238-246.

Jonsson, E. G., Goldman, D., Spurlock, G., Gustavsson, J. P., Nielsen, D. A., Linnoila, M., Owen, M. J. \& Sedvall, G. C. (1997) Tryptophan hydroxylase and catechol-O-methyltransferase gene polymorphisms: relationships to monoamine metabolite concentrations in CSF of healthy volunteers. European Archives of Psychiatry and Clinical Neuroscience 247, 297-302.

Kessler, R. C., Borges, G. \& Walters, E. E. (1999). Prevalence of and risk factors for lifetime suicide attempts in the National Comorbidity Survey. Archives of General Psychiatry 56, 617-626.

Lerman, C., Caporaso, N. E., Bush, A., Zheng, Y.-L., Audrain, J., Main, D. \& Shields, P. G. (2001). Tryptophan hydroxylase gene variant and smoking behavior. American Journal of Medical Genetics (Neuropsychiatric Genetics) 105, 518-520.

Malhotra, A. K. \& Goldman, D. (1999). Benefits and pitfalls encountered in psychiatric genetic association studies. Biological Psychiatry 45, 544-550.

Mann, J. J. (1998). The neurobiology of suicide. Nature Medicine 4 $25-30$.

Mann, J. J. (1999). Role of the serotonergic system in the pathogenesis of major depression and suicidal behavior. Neuropsychopharmacology 21, 99S-105S

Mann, J. J., Malone, K. M., Nielsen, D. A., Goldman, J., Erdos, J. \& Gelertner, J. (1997). Possible association of a polymorphism of the tryptophan hydroxylase gene with suicidal behavior in depressed patients. American Journal of Psychiatry 154, 1451-1453.

Mann, J. J., Huang, Y. Y., Underwood, M. D., Kassir, S. A., Oppenheim, S., Kelly, T. M., Dwork, A. J. \& Arango, V. (2000). A serotonin transporter gene promoter polymorphism (5-HTTLPR) and prefrontal cortical binding in major depression and suicide. Archives of General Psychiatry 57, 729-738.

Mann, J. J., Brent, D. A. \& Arango, V. (2001). The neurobiology and genetics of suicide and attempted suicide: a focus on the serotonergic system. Neuropsychopharmacology 24, 467-477.

Manuck, S. B., Flory, J. D., Ferrell, R. E., Dent, K. M., Mann, J. J. \& Muldoon, M. F. (1999). Aggression and anger-related traits associated with a polymorphism of the tryptophan hydroxylase gene. Biological Psychiatry 45, 603-614.

Marshall, S. E., Bird, T. G., Hart, K. \& Welsh, K. I. (1999). Unified approach to the analysis of genetic variation in serotonergic pathways. American Journal of Medical Genetics 88, 621-627. 
Moscicki, E. K. (1997). Identification of suicide risk factors using epidemiologic studies. Psychiatric Clinics of North America 20, 499-517.

New, A. S., Gelernter, J., Goodman, M., Mitropoulou, V., Koenigsberg, H., Silverman, J. \& Siever, L. J. (2001). Suicide, impulsive aggression, and HTR1B genotype. Biological Psychiatry 50, 62-65.

Nielsen, D. A., Goldman, D., Virkkunen, M., Tokola, R., Rawlings, R. \& Linnoila, M. (1994). Suicidality and 5-hydroxyindoleacetic acid concentration associated with a tryptophan hydroxylase polymorphism. Archives of General Psychiatry 51, 34-38.

Nielsen, D. A., Jenkins, G. L., Stefanisko, K. M., Jefferson, K. K. \& Goldman, D. (1997). Sequence, splice site and population frequency distribution analyses of the polymorphic human tryptophan hydroxylase intron 7. Molecular Brain Research 45, 145-148.

Nielsen, D. A., Virkkunen, M., Lappalainen, J., Eggert, M., Brown, G. L., Long, J. C. \& Linnoila, M. (1998). A tryptophan hydroxylase gene marker for suicidality and alcoholism. Archives of General Psychiatry 55, 593-602.

Ono, H., Shirakawa, O., Nishiguchi, N., Nishimura, A., Nushida, H., Ueno, Y. \& Maeda, K. (2000). Tryptophan hydroxylase gene polymorphisms are not associated with suicide. American Journal of Medical Genetics 96, 861-863.

Persson, M.-L. (1999). Suicide Attempts and Genes. Psychiatric and Genetic Characteristics of Suicide Attempters. Kongl Karolinska Medico Chirurgiska Institutet: Stockholm. (Cited in Mann et al. (2001).)

Platt, S., Bille-Brahe, U., Kerkhof, A., Schmidtke, A., Bjerke, T., Crepet, P., De Leo, D., Haring, C., Lonnqvist, J., Michel, K., Phillipe, A., Pommerau, X., Querejeta, I., Salander-Renberg, E., Temesvary, B., Wasserman, D. \& Sampaio, Faria, J. (1992). Parasuicide in Europe: the WHO/EURO multicentre study on parasuicide. I. Introduction and preliminary analysis for 1989 Acta Psychiatrica Scandinavica 85, 97-104.

Plutchik, R., Van Praag, H., Picard, S., Conte, H. \& Korn, M. (1989). Is there a relationship between the seriousness of suicidal intent and the lethality of the suicide attempt? Psychiatry Research 27, 71-79.

Qin, P., Agerbo, E. \& Mortensen, P. B. (2002). Suicide risk in relation to family history of completed suicide and psychiatric disorders: a nested case-control study based on longitudinal registers. Lancet 360, 1126-1130.

Rotondo, A., Schuebel, K., Bergen, A., Aragon, R., Virkkunen, M., Linnoila, M., Goldman, D. \& Nielsen, D. (1999). Identification of four variants in the tryptophan hydroxylase promoter and association to behavior. Molecular Psychiatry 4, 360-368.

Roy, A. (1983). Family history of suicide. Archives of General Psychiatry 40, 971-974.

Roy, A. (2001). Genetic influences on suicide risk. Clinical Neuroscience Research 1, 324-330.

Roy, A., Nielsen, D., Rylander, G. \& Sarchiapone, M. (2000). The genetics of suicidal behaviour. In The International Handbook of Suicide and Attempted Suicide (ed. K. Hawton and K. van Heeringen), pp. 209-221. John Wiley: Chichester.

Russ, M., Lachmann, H., Kashdan, T., Saito, T. \& BajmakovicKacila, S. (2000). Analysis of catechol-o-methyltransferase and 5-hydroxytryptamine transporter polymorphisms in patients at risk for suicide. Psychiatry Research 93, 73-78.
Sakinofsky, I. (2000). Repetition of suicidal behaviour. In The International Handbook of Suicide and Attempted Suicide (ed. K. Hawton and K. van Heeringen), pp. 385-404. John Wiley: Chichester

Statham, D. J., Heath, A. C., Madden, P. A. F., Bucholz, K. K., Bierut, L., Dinwiddie, S. H., Slutske, W. S., Dunne, M. P. \& Martin, N. G. (1998). Suicidal behaviour: an epidemiological and genetic study. Psychological Medicine 28, 839-855.

Sullivan, P. F., Jiang, Y., Neale, M. C., Kendler, K. S. \& Straub, R. E. (2001). Association of the tryptophan hydroxylase gene with smoking initiation but not progression to nicotine dependence. American Journal of Medical Genetics (Neuropsychiatric Genetics) $105,479-484$.

Suominen, K., Henriksson, M., Suokas, J., Isometsa, E., Ostamo, A. \& Lonnqvist, J. (1996). Mental disorders and comorbidity in attempted suicide. Acta Psychiatrica Scandinavica 94, 234-240.

Tsai, S. J., Hong, C. J. \& Wang, Y. C. (1999a). Tryptophan hydroxylase gene polymorphism (A218C) and suicidal behaviors. Neuroreport 10, 3773-3775.

Tsai, S. J., Hong, C. J., Hsu, C. C., Cheng, C. Y., Liao, W. Y., Song, H. L. \& Lai, H. C. (1999b). Serotonin-2A receptor polymorphism $(102 \mathrm{~T} / \mathrm{C})$ in mood disorders. Psychiatry Research 87, 233-237.

Turecki, G. (2001). Suicidal behavior: is there a genetic predisposition? Bipolar Disorders 3, 335-349.

Turecki, G., Briere, R., Dewar, K., Antonetti, T., Lesage, A. D., Seguin, M., Chawky, N., Vanier, C., Alda, M., Joober, R., Benkelfat, C. \& Rouleau, G. A. (1999). Prediction of level of serotonin $2 \mathrm{~A}$ receptor binding by serotonin receptor $2 \mathrm{~A}$ genetic variation in postmortem brain samples from subjects who did or did not commit suicide. American Journal of Psychiatry 156, $1456-1458$.

Turecki, G., Zhu, Z., Tzenova, J., Lesage, A., Seguin, M., Tousignant, M., Chawky, N., Vanier, C., Lipp, O., Alda, M., Joober, R., Benkelfat, C. \& Rouleau, G. A. (2001). TPH and suicidal behavior: a study in suicide completers. Molecular Psychiatry 6 98-102.

Van Praag, H. M. (2001). About the biological interface between psychotraumatic experiences and affective dysregulation. In Understanding Suicidal Behaviour: The Suicidal Process Approach to Research, Treatment and Prevention (ed. K. van Heeringen), pp. 54-75. John Wiley: Chichester.

Wacholder, S., Rothman, N. \& Caporaso, N. (2000). Population stratification in epidemiological studies of common genetic variants and cancer: quantification of bias. Journal of the National Cancer Institute 92, 1151-1158.

World Health Organization (1993). The ICD-10 Classification of Mental and Behavioural Disorders: Diagnostic Criteria for Research. World Health Organization: Geneva.

Zalsman, G., Frisch, A., King, R. A., Pauls, D. A., Grice, D. E., Gelertner, J., Alsobrook, J., Michaelovsky, E., Apter, A., Tyano, S., Weizman, A. \& Leckman, J. F. (2001). Case-control and family-based studies of tryptophan hydroxylase gene A218C polymorphism and suicidality in adolescents. American Journal of Medical Genetics (Neuropsychiatric Genetics) 105, 451-457.

Zhang, H.-Y., Ishigaki, T., Tani, K., Chen, K., Shih, J. C., Miyasato, K. \& Ohara, K. (1997). Serotonin 2 A receptor gene polymorphism in mood disorders. Biological Psychiatry 41, 768-773. 